\title{
Chromenes and Prenylated Benzoic Acid Derivatives from the Liverwort Pedinophyllum interruptum
}

\author{
Hildegard Feld ${ }^{\mathrm{a}}$, David S. Rycroft ${ }^{\mathrm{b}}$, and Josef Zapp ${ }^{\mathrm{a}}$ \\ ${ }^{\text {a }}$ FR 8.7, Pharmakognosie und Analytische Phytochemie der Universität des Saarlandes, \\ 66041 Saarbrücken, Germany \\ b Chemistry Department, The University of Glasgow, Glasgow G12 8QQ, Scotland, UK \\ Reprint requests to Dr. Josef Zapp. Fax: +49-681-302-2476. E-mail: j.zapp@ mx.uni-saarland.de
}

Z. Naturforsch. 59b, 825 - 828 (2004); received November 27, 2003

\begin{abstract}
The chemical composition of a diethyl ether extract of the Scottish liverwort Pedinophyllum interruptum has been examined. Two new prenylated benzoic acid derivatives, methyl 2,6dihydroxy-4-methoxy-3-(3'-methyl-2'-butenyl)benzoate and methyl 2,4,6-trihydroxy-3-(3'-methyl2'-butenyl)benzoate, two new chromenes, methyl 5,7-dihydroxy-2,2-dimethyl-2H-chromene-6carboxylate and methyl 7-hydroxy-5-methoxy-2,2-dimethyl-2H-chromene-8-carboxylate, and the two known chromenes methyl 8-hydroxy-2,2-dimethyl-2 $H$-chromene-6-carboxylate and methyl 8methoxy-2,2-dimethyl- $2 \mathrm{H}$-chromene-6-carboxylate were isolated. Methyl 2,4,6-trihydroxy-3-(3'methyl-2'-butenyl)benzoate was unstable in air and was quickly converted into methyl 2,4,6trihydroxy-3-(2'-hydroperoxy-3'-methyl-3'-butenyl)benzoate. All structures were elucidated by means of NMR spectroscopic techniques and mass spectrometry.
\end{abstract}

Key words: Pedinophyllum interruptum, Prenylated Benzoic Acid Derivatives, Chromenes

\section{Introduction}

Pedinophyllum interruptum (Nees) Kaal., is one of only four species of the genus Pedinophyllum (Plagiochilaceae). It grows in Europe, West Russia and Eastern North America. The plant is rare in Europe and has been over-recorded in the past because of confusion with certain forms of Plagiochila porelloides that often occur in the same habitat [1]. No previous phytochemical studies have been carried out on this species. In continuing our investigations on the constituents of liverworts [2-4] we now report the identification of six simple phenolic compounds, the prenylated benzoic acid derivatives $\mathbf{1}$ and $\mathbf{2}$ and the chromenes 4-7, from a diethyl ether extract of $P$. interruptum. Chromenes $\mathbf{6}$ and $\mathbf{7}$ are known compounds [5].

\section{Results}

A small sample of the liverwort $P$. interruptum was extracted with diethyl ether and six uv active compounds were isolated: the new natural products $\mathbf{1}, \mathbf{2}, \mathbf{4}$ and 5 and two known substances, methyl 8hydroxy-2,2-dimethyl-2H-chromene-6-carboxylate $\mathbf{6}$ and methyl 8-methoxy-2,2-dimethyl- $2 \mathrm{H}$-chromene-6carboxylate 7 (Fig. 1). Assignments of the ${ }^{1} \mathrm{H}$ and ${ }^{13} \mathrm{C}$ data for 1, 3, 4 and 5 were carried out with the aid of HMQC, HMBC and NOESY experiments. Only the ${ }^{1} \mathrm{H}$ NMR spectrum of $\mathbf{2}$ was obtained before it was transformed to the hydroperoxide $\mathbf{3}$ (Fig. 1). Compounds 6 and 7 were identified by their ${ }^{1} \mathrm{H}$ NMR data which were consistent with the literature values [5]. This is the first report of $\mathbf{7}$ as a natural product.

Compound $\mathbf{1}$ was obtained as a colourless oil which slowly solidified to crystals, m.p. $72-73{ }^{\circ} \mathrm{C}$. HREIMS analysis gave a parent ion at $m / z 266.1154$ which supported the molecular formula $\mathrm{C}_{14} \mathrm{H}_{18} \mathrm{O}_{5}$. The ${ }^{1} \mathrm{H}$ and ${ }^{13} \mathrm{C}$ NMR spectra in $\mathrm{CDCl}_{3}$ showed the signals of a di-C-substituted phloroglucinol moiety with three oxygenated aromatic carbons at $\delta_{\mathrm{C}} 164.6,161.3$ and 159.1 and only one aromatic proton at $\delta_{\mathrm{H}} 6.06$. The two substituents were revealed as a carbomethoxyl group $\left(\delta_{\mathrm{C}} 170.3,52.6 ; \delta_{\mathrm{H}} 4.03, s\right)$ and a prenyl side chain $\left[\delta_{\mathrm{H}} 3.25\left(\mathrm{~d}, J=6.9 \mathrm{~Hz}, 2 \times \mathrm{H}-1^{\prime}\right), \delta_{\mathrm{C}} 21.9\left(\mathrm{C}^{\prime} 1^{\prime}\right) ; \delta_{\mathrm{H}}\right.$ $5.16\left(\mathrm{t}, J=6.9 \mathrm{~Hz}, \mathrm{H}-2^{\prime}\right), \delta_{\mathrm{C}} 123.2\left(\mathrm{C}^{\prime} 2^{\prime}\right) ; \delta_{\mathrm{C}} 131.4$ $\left(\mathrm{C}^{-} 3^{\prime}\right) ; \delta_{\mathrm{H}} 1.76\left(\mathrm{~s}, 3 \times \mathrm{H}^{\prime} 5^{\prime}\right), \delta_{\mathrm{C}} 18.0\left(\mathrm{C}^{-5}{ }^{\prime}\right) ; \delta_{\mathrm{H}} 1.67(\mathrm{~s}$, $\left.\left.3 \times \mathrm{H}-4^{\prime}\right), \delta_{\mathrm{C}} 26.0\left(\mathrm{C}-4^{\prime}\right)\right]$. In addition, the resonances of a methoxy group $\left(\delta_{\mathrm{C}} 55.9, \delta_{\mathrm{H}} 3.83, s\right)$ were observed. The HMBC spectrum showed it was attached to the oxygenated aromatic carbon at $\delta_{\mathrm{C}}$ 164.6. A NOE difference experiment showed an effect between the aromatic proton and the protons of the methoxy group, hence the two were vicinal. Since H-1' corre- 
<smiles>[R]Oc1cc(O)c(C(=O)OC)c(O)c1[C]C=C(C)C</smiles><smiles>C=C(C)[C@H](O)Cc1c(O)cc(O)c(C(=O)OC)c1O</smiles><smiles>COC(=O)c1c(O)cc2c(c1O)C=CC(C)(F)O2</smiles>

4

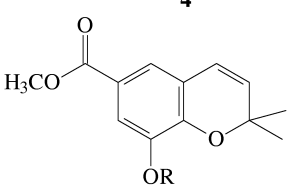

$6 \mathrm{R}=\mathrm{H}$

$7 \mathrm{R}=\mathrm{CH}_{3}$

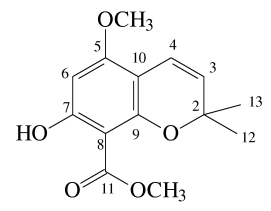

5

Fig. 1. Structures of methyl 2,6-dihydroxy-4-methoxy3-(3'-methyl-2'-butenyl)benzoate (1), methyl 2,4,6-trihydroxy-3-(3'-methyl-2'-butenyl)benzoate (2), methyl 2,4,6-trihydroxy-3-(2'-hydroperoxy-3'-methyl-3'-butenyl)benzoate (3), methyl 5,7-dihydroxy-2,2-dimethyl-2Hchromene-6-carboxylate (4), methyl 7-hydroxy-5-methoxy-2,2-dimethyl-2H-chromene-8-carboxylate (5), methyl 8-hydroxy-2,2-dimethyl-2H-chromene-6-carboxylate (6) and methyl 8-methoxy-2,2-dimethyl-2H-chromene-6-carboxylate (7).

lated with the oxygenated carbon at $\delta_{\mathrm{C}} 164.6$ in the HMBC the prenyl side chain was also vicinal to the methoxy group. Hence the carbomethoxyl group had to be positioned between the two remaining hydroxyl groups leading to structure 1, methyl 2,6-dihydroxy4-methoxy-3-(3'-methyl-2'-butenyl)benzoate, for this compound, which is a new natural product. It has already been mentioned in a publication on the synthesis of phloroglucinol derivates but no data except for the melting point were given [6].

Compound 2 was detected in the GC-MS spectrum of the crude extract $\left(\mathrm{m} / \mathrm{z}, 252[\mathrm{M}]^{+}\right)$but could not be isolated at first due to its instability. Therefore another small sample of the same plant was extracted and 2 was isolated immediately. A HREIMS $(\mathrm{m} / \mathrm{z}=$ $\left.252.0999[\mathrm{M}]^{+}, \mathrm{C}_{13} \mathrm{H}_{16} \mathrm{O}_{5}\right)$ and a ${ }^{1} \mathrm{H}$ NMR spectrum in $\mathrm{C}_{6} \mathrm{D}_{6}$ could be recorded before the molecule decomposed to give compound 3 . For better comparison, the NMR data of $\mathbf{1}$ in $\mathrm{C}_{6} \mathrm{D}_{6}$ are also given in the experimental. The ${ }^{1} \mathrm{H}$ NMR spectrum of compound 2 was very similar to that of $\mathbf{1}$ and revealed an aromatic proton at $\delta_{\mathrm{H}} 5.99(\mathrm{~s}, \mathrm{H}-5)$, a prenyl side chain $\left[\delta_{\mathrm{H}} 3.56(\mathrm{~d}\right.$,

$\left.J=7.3 \mathrm{~Hz}, 2 \times \mathrm{H}^{\prime} 1^{\prime}\right) ; \delta_{\mathrm{H}} 5.47\left(\mathrm{t}, J=7.3 \mathrm{~Hz}, \mathrm{H}-2^{\prime}\right)$; $\left.\delta_{\mathrm{H}} 1.73\left(\mathrm{~s}, 3 \times \mathrm{H}-5^{\prime}\right) ; \delta_{\mathrm{H}} 1.61\left(\mathrm{~s}, 3 \times \mathrm{H}^{\prime} 4^{\prime}\right)\right]$ and, in contrast to 1 , only one methoxy group at $\delta_{\mathrm{H}} 2.94$. Since the structural elucidation of $\mathbf{3}$, described below, clearly showed the presence of a methyl ester the structure of 2 was established as methyl 2,4,6-trihydroxy-3-(3'methyl-2'-butenyl)benzoate.

The parent ion of 3 in the EIMS was at $m / z$ $284\left(\mathrm{C}_{13} \mathrm{H}_{16} \mathrm{O}_{7}\right)$ and thus 3 contained two more oxygens than compound 2 . The ${ }^{1} \mathrm{H}$ and ${ }^{13} \mathrm{C}$ NMR spectra $\left(\mathrm{C}_{6} \mathrm{D}_{6}\right)$ showed resonances for an aromatic proton $\left(\delta_{\mathrm{H}} 6.24, \mathrm{~s}\right)$, three oxygenated aromatic carbons $\left(\delta_{\mathrm{C}} 162.3,160.9,156.3\right)$ and a carbomethoxyl group $\left(\delta_{\mathrm{C}} 170.2,51.5 ; \delta_{\mathrm{H}} 2.94, \mathrm{~s}\right)$ revealing that the two molecules had the same aromatic moiety but differed in the prenyl side chain. The double bond was now between C-3' and C-4' $\left(\delta_{\mathrm{C}} 144.3,113.0\right)$ as deduced from the ${ }^{1} \mathrm{H}$ NMR spectrum which showed signals for the two methylene protons $\left(\delta_{\mathrm{H}} 5.05\right.$, brs, $2 \times \mathrm{H}-4$ ' $)$ and for the methyl group C-5' $\left(\delta_{\mathrm{H}} 1.81\right)$ attached to it. The carbon at C-2' was oxidised to a hydroperoxide which resulted in a characteristic downfield shift for C-2' to $\delta_{\mathrm{C}} 88.7$. These assignments were also confirmed by comparison with the data for similar side chains [7]. The hydroperoxide was also not stable and eventually decomposed to a complex mixture of products.

The ${ }^{1} \mathrm{H}$ NMR of $\mathbf{4}$ showed signals for two methyl groups (both $\delta_{\mathrm{H}} 1.39, \mathrm{H}-12$ and $\mathrm{H}-13$ ) attached to an oxygen-bearing carbon and two olefinic protons at $\delta_{\mathrm{H}} 5.54$ and $6.50(J=10.1 \mathrm{~Hz}$ each $)$ indicating the heterocyclic part of a 2,2-dimethyl- $2 \mathrm{H}$-chromene moiety. The ${ }^{13} \mathrm{C} \mathrm{NMR}$ spectrum in $\mathrm{CDCl}_{3}$ showed only four signals for the aromatic ring subunit: three aromatic carbons $\left(\delta_{\mathrm{C}} 125.8,115.9,102.2\right)$ and one oxygenated carbon $\left(\delta_{\mathrm{C}} 160.5\right)$. However, in a different solvent (DMSO- $\left.d_{6}\right)$ the signals of three oxygenated carbons $\left(\delta_{\mathrm{C}} 160.8,158.7,156.8\right)$ were revealed, indicating a phloroglucinol moiety. The highfield chemical shift of the only aromatic proton at $\delta_{\mathrm{H}} 5.90(s$, $\mathrm{H}-8)$ supported this conclusion. The ring carried a carbomethoxyl group $\left(\delta_{\mathrm{C}} 170.3,52.4, \delta_{\mathrm{H}} 3.84\right)$ that should be attached either to C-6 or to C-8. In the ${ }^{1} \mathrm{H}$ NMR spectrum in DMSO- $d_{6}$ the signals of two chelated hydroxyls appeared at $\delta_{\mathrm{H}} 10.99$ and 10.21, indicating that the carbomethoxyl group had to be at C-6, vicinal to both hydroxyls. Further proof of this structure was provided by a NOESY experiment in DMSO- $d_{6}$ in which correlations of $\mathrm{H}-8$ with the proton of C-7-OH and the geminal methyls $\mathrm{H}-12$ and $\mathrm{H}-13$ were observed. Thus the structure of $\mathbf{4}$ was elucidated 
as methyl 5,7-dihydroxy-2,2-dimethyl- $2 H$-chromene6-carboxylate.

Compound $\mathbf{5}$ was also a chromene derivative. Initially we thought it was a methyl ether of $\mathbf{4}$ because of the similarity of the ${ }^{1} \mathrm{H}$ and ${ }^{13} \mathrm{C}$ NMR spectra: there was a phloroglucinol moiety with three oxygenated carbons $\left(\delta_{\mathrm{C}} 164.6,160.1\right.$ and 155.6) and a highfield aromatic proton $\left(\delta_{\mathrm{H}} 6.00\right)$. One of the hydroxyls was methylated $\left(\delta_{\mathrm{C}} 55.6, \delta_{\mathrm{H}} 3.76\right)$ and the second hydroxyl $\left(\delta_{\mathrm{H}} 11.82\right)$ was vicinal to the methyl ester $\left(\delta_{\mathrm{C}} 171.6\right.$, $\left.51.8, \delta_{\mathrm{H}} 3.84\right)$. However, the correlations in the HMBC showed that the position of the methyl ester was not at $\mathrm{C}-6$ as in 4 but at C-8. The oxygenated carbons at $\delta_{\mathrm{C}} 160.1$ and 155.6 had ${ }^{3} J_{\mathrm{CH}}$-correlations from the double bond proton $\mathrm{H}-4$ at $\delta_{\mathrm{H}} 6.46$ and should therefore be either C-5 or C-9. The methoxy group was attached to the carbon at $\delta_{\mathrm{C}} 160.1$. Since it is impossible for C-9 to carry a methoxy group the carbon at $\delta_{\mathrm{C}} 160.1$ was assigned to C-5. Accordingly, the carbon at $\delta_{\mathrm{C}} 155.6$ had to be attributed to C-9. Thus the remaining hydroxyl bearing carbon $\left(\delta_{\mathrm{C}} 164.6\right)$ was assigned to C-7. C-5 and C-7 had ${ }^{2} J_{\mathrm{CH}}$-correlations from the aromatic proton. If this were $\mathrm{H}-8$ it should correlate with C-7 and C-9, while H-6 should correlate with C-5 and $\mathrm{C}-7$. Hence the aromatic proton had to be at position 6 and the methyl ester attached to C- 8 . This structure was further supported by a NOESY experiment which revealed effects between the aromatic proton and the protons of the methoxy group at $\mathrm{C}-5$. Thus the structure of 5 was established as methyl 7-hydroxy-5methoxy-2,2-dimethyl- $2 \mathrm{H}$-chromene-8-carboxylate. It seems likely that the prenylated benzoic acids $\mathbf{1}$ and $\mathbf{2}$ are the biogenetic precursors of the chromenes $\mathbf{5}$ and $\mathbf{4}$ respectively.

2,2-Dimethyl-2H-chromenes are widespread in many higher plants, especially in Asteraceae [89] and Rutaceae [10]. However, they are rare liverwort constituents. The only chromene derivatives that have been reported are structural variations of prenylated bibenzyls in which a prenyl side chain of the bibenzyl is cyclised to give 2,2-dimethylchromene derivatives. These were isolated from the liverworts Radula kojana [11], $R$. perrottetii and $R$. complanata [12], $R$. laxiramea [3] and Lethocolea glossophylla [13]. Recently methyl 5,7-dihydroxy-2,2-dimethyl-2H-chromene-6carboxylate and methyl 7-hydroxy-5-methoxy-2,2dimethyl- $2 \mathrm{H}$-chromene-8-carboxylate were also isolated from another Hepaticae species, Adelanthus lindenbergianus [14].

\section{Experimental Section}

Spectroscopy

${ }^{1} \mathrm{H}$ NMR (400 MHz) and ${ }^{13} \mathrm{C}$ NMR (100 MHz) spectra were recorded on a BRUKER DPX-400 spectrometer. The chemical shifts are given in $\delta$ values (ppm) relative to TMS as internal standard; 2D spectra were recorded as $\mathrm{H}, \mathrm{H}-$ COSY, HMQC and HMBC experiments. The UV spectra were recorded on a Shimadzu UV mini-1240 UV-vis spectrophotometer, while IR spectra were recorded on a Jasco FR-IR-410 spectrophotometer. Mass spectra were recorded in the positive EI mode on a Jeol JMS-700 instrument.

\section{Plant material}

P. interruptum (Nees) Kaal. was collected in Glen Stockdale, Scotland and identified by DSR in September 1998. A voucher specimen is retained in the Chemistry Department, University of Glasgow.

\section{Extraction and isolation}

$2.5 \mathrm{~g}$ powdered, air dried plant material was extracted with $\mathrm{Et}_{2} \mathrm{O}$. The extract $(230 \mathrm{mg}$ ) was separated by VLC on diol silica (diol silica gel $40-63 \mu \mathrm{m}$, stepwise with a $n$-hexane-EtOAc gradient) gel to give 9 fractions (AI). HPLC of fraction B (1-1.5\% EtOAc) on silica gel (LiChrospher Si 100, $5 \mu \mathrm{m}, 4 \times 250 ; n$-hexane:EtOAc 96:4) gave $4(1 \mathrm{mg}), 5(1 \mathrm{mg})$ and $1(6 \mathrm{mg})$. Fraction $\mathrm{C}(8-10 \%$ EtOAc) was methyl 8-methoxy-2,2-dimethyl$2 H$-chromene-6-carboxylate 7 ( $1 \mathrm{mg}$ ), HPLC (LiChrospher Si 100, $5 \mu \mathrm{m}, 4 \times 250 ; n$-hexane:EtOAc 90:10) of fraction E (7-10\% EtOAc) yielded methyl 8-hydroxy-2,2-dimethyl2H-chromene-6-carboxylate 6 (1 mg) (Orjala et al., 1993). Fraction $\mathrm{H}(18-20 \%$ EtOAc) was also pure and yielded 2 (1 mg).

\section{Spectroscopic data}

Methyl 2,6-dihydroxy-4-methoxy-3-(3'-methyl-2'-butenyl)benzoate (1)

Colourless oil, which solidifies readily. - M.p. $72-73{ }^{\circ} \mathrm{C}$ $\left(\mathrm{CH}_{2} \mathrm{Cl}_{2}\right)$. - UV $\left(\mathrm{CHCl}_{3}\right): \lambda_{\max }=273,318 \mathrm{~nm}$. - IR (film) $v=3415,2960,2925,2855,1675,1645,1590,1430$, 1285, 1155, $1105 \mathrm{~cm}^{-1}$. - ${ }^{1} \mathrm{H}$ NMR $\left(\mathrm{CDCl}_{3}\right): \delta=6.06$ (s, H-5), 5.16 (t, $J=6.9 \mathrm{~Hz}, \mathrm{H}-2$ ') $4.03\left(\mathrm{~s}, \mathrm{COOCH}_{3}\right)$, $3.83\left(\mathrm{~s}, \mathrm{OCH}_{3}\right), 3.25\left(\mathrm{~d}, J=6.9 \mathrm{~Hz}, 2 \times \mathrm{H}-1^{\prime}\right), 1.76(\mathrm{~s}$, $3 \times \mathrm{H}^{-5}$ '), $1.67\left(\mathrm{~s}, 3 \times \mathrm{H}-4^{\prime}\right) .-{ }^{1} \mathrm{H}$ NMR $\left(\mathrm{C}_{6} \mathrm{D}_{6}\right): \delta=$ $6.11(\mathrm{~s}, \mathrm{H}-5), 5.63$ (t, $J=7.2 \mathrm{~Hz}, \mathrm{H}-2$ '), 3.68 (d, $J=$ $\left.7.2 \mathrm{~Hz}, 2 \times \mathrm{H}^{-1}{ }^{\prime}\right), 3.18\left(\mathrm{~s}, \mathrm{OCH}_{3}\right), 2.97\left(\mathrm{~s}, \mathrm{COOCH}_{3}\right)$, 1.88 (s, $3 \times \mathrm{H}-5$ '), 1.71 (s, $\left.3 \times \mathrm{H}-4^{\prime}\right) .-{ }^{13} \mathrm{C}\left\{{ }^{1} \mathrm{H}\right\} \mathrm{NMR}$ $\left(\mathrm{CDCl}_{3}\right): \delta=170.3\left(\mathrm{COOCH}_{3}\right), 164.6(\mathrm{C}-4), 161.3(\mathrm{C}-6)$, 159.11 (C-2), 131.4 (C-3'), 123.2 (C-2'), 109.4 (C-3), $94.1(\mathrm{C}-1), 92.0(\mathrm{C}-5), 55.9\left(\mathrm{OCH}_{3}\right), 52.6\left(\mathrm{COOCH}_{3}\right)$, 26.0 (C-4'), 21.9 (C-1'), 18.0 (C-5'). $-{ }^{13} \mathrm{C}\left\{{ }^{1} \mathrm{H}\right\}$ NMR $\left(\mathrm{C}_{6} \mathrm{D}_{6}\right): \delta=170.2\left(\mathrm{COOCH}_{3}\right), 164.6(\mathrm{C}-4), 161.7(\mathrm{C}-2)$, 159.0 (C-6), 130.7 (C-3'), 123.9 (C-2'), 109.2 (C-3), 94.3 
(C-1), 92.0 (C-5), $55.1\left(\mathrm{OCH}_{3}\right), 51.5\left(\mathrm{COOCH}_{3}\right), 26.0$ (C-4'), 22.2 (C-1'), 17.9 (C-5'). - MS (EI, $70 \mathrm{eV}): m / z(\%)=$ $266(92)[\mathrm{M}]^{+}, 251(21), 234$ (28), 219 (100), 206 (44), 191 (46), 179 (84), 166 (17), 149 (7), 69 (13). - HREIMS: $m / z=266.1154[\mathrm{M}]^{+}$(calcd. for $\mathrm{C}_{14} \mathrm{H}_{18} \mathrm{O}_{5}$ 266.1154).

Methyl 2,4,6-trihydroxy-3-(3'-methyl-2'-butenyl)benzoate (2)

Colourless oil. $-{ }^{1} \mathrm{H}$ NMR $\left(\mathrm{C}_{6} \mathrm{D}_{6}\right): \delta=5.99(\mathrm{~s}, \mathrm{H}-5)$, 5.47 (t, $J=7.3 \mathrm{~Hz}, \mathrm{H}-2$ '), 3.56 (d, $J=7.3 \mathrm{~Hz}, 2 \times \mathrm{H}^{-1}$ '), $2.94\left(\mathrm{~s}, \mathrm{COOCH}_{3}\right), 1.73$ (s, $3 \times \mathrm{H}-5$ '), 1.61 (s, $\left.3 \times \mathrm{H}-4^{\prime}\right)$. MS (EI, $70 \mathrm{eV}): m / z(\%)=252(100)[\mathrm{M}]^{+}, 237(16)$, 220 (41), 205 (83), 192 (50), 177 (50), 165 (87), 152 (14), 123 (10), 69 (20). - HREIMS: $m / z=252.0999[\mathrm{M}]^{+}$(calcd. for $\mathrm{C}_{13} \mathrm{H}_{16} \mathrm{O}_{5}$ 252.0998).

Methyl 2,4,6-trihydroxy-3-(2'-hydroperoxy-3'-methyl-3'butenyl)benzoate (3)

Colourless oil. $-{ }^{1} \mathrm{H}$ NMR $\left(\mathrm{C}_{6} \mathrm{D}_{6}\right): \delta=6.24(\mathrm{~s}, \mathrm{H}-5), 5.03$ (brs, H-4'a), 4.91 (brs, H-4'b), 4.58 (dd, $J=3.5,8.7 \mathrm{~Hz}$, H-2'), 3.18 (dd, $J=3.5,14.8 \mathrm{~Hz}, \mathrm{H}-1$ 'a), 2.98 (dd, $J=8.7$, $14.8 \mathrm{~Hz}, \mathrm{H}-1$ 'b), 2.94 (s, $\left.\mathrm{COOCH}_{3}\right), 1.81$ (s, $3 \times \mathrm{H}-5^{\prime}$ '). ${ }^{1} \mathrm{H}$ NMR $\left(\mathrm{CDCl}_{3}\right): \delta=6.06$ (s, H-5), 5.05 (brs, $2 \times \mathrm{H}-4$ '), $4.46\left(\mathrm{dd}, J=2.9,9.0 \mathrm{~Hz}, \mathrm{H}-2\right.$ '), $4.04\left(\mathrm{~s}, \mathrm{COOCH}_{3}\right), 3.06$ (dd, $J=2.9,15.1 \mathrm{~Hz}, \mathrm{H}-1$ ' a), 2.78 (dd, $J=9.0,15.1 \mathrm{~Hz}$, $\mathrm{H}-1$ 'b), 1.87 (s, $3 \times \mathrm{H}-5$ '). $-{ }^{13} \mathrm{C}\left\{{ }^{1} \mathrm{H}\right\}$ NMR $\left(\mathrm{C}_{6} \mathrm{D}_{6}\right): \delta=$ $170.2\left(\mathrm{COOCH}_{3}\right), 162.3(\mathrm{C}-4), 160.9\left(\mathrm{C}-6^{*}\right), 156.3\left(\mathrm{C}-2^{*}\right)$, 144.3 (C-3'), 113.0 (C-4'), 104.8 (C-3), 96.8 (C-5), 94.2 (C-1), 88.7 (C-2'), $51.5\left(\mathrm{COOCH}_{3}\right), 24.9$ (C-1'), 19.0 (C-5'). MS (EI, $70 \mathrm{eV}): m / z(\%)=284(2)[\mathrm{M}]^{+}, 268(10), 252(22)$, 211 (36), 197 (46), 179 (58), 165 (100), 70 (16), 41 (19).

${ }^{*}$ Assigments interchangeable.

Methyl 5,7-dihydroxy-2,2-dimethyl-2H-chromene-6carboxylate (4)

Yellow oil. - UV $\left(\mathrm{CHCl}_{3}\right): \lambda_{\max }=264,337 \mathrm{~nm}$. IR (film) $v=3400,2950,1650,1580,1450,1375,1050$,

[1] M. O. Hill, C.D. Preston, A. J. E. Smith, Atlas of the Bryophytes of Britain and Ireland. Liverworts, Vol. 1. Harley Books, Essex (1991).

[2] U. M. Hertewich, J. Zapp, H. Becker, Phytochemistry 63, 227 (2003).

[3] F. Cullmann, H. Becker, Z. Naturforsch. 54C, 147 (1999).

[4] U. Martini, J. Zapp, H. Becker, Phytochemistry 47, 89 (1998).

[5] J. Orjala, C. A. J. Erdelmeier, A. D. Wright, T. Rali, O. Sticher, Phytochemistry 34, 813 (1993).

[6] M. Vandewalle, M. Verzele, Bull. Soc. Chim. Belg. 68, 711 (1959).

[7] C. Ito, Y. Miyamoto, M. Nakayama, Y. Kawai, K. S. Rao, H. Furukawa, Chem. Pharm. Bull. 45, 1403 (1997).
$950 \mathrm{~cm}^{-1} .-{ }^{1} \mathrm{H}$ NMR $\left(\mathrm{CDCl}_{3}\right): \delta=6.58(\mathrm{~d}, J=10.0 \mathrm{~Hz}$, H-4), 5.90 (s, H-8), 5.42 (d, $J=10.0 \mathrm{~Hz}, \mathrm{H}-3), 3.99$ (s, $\mathrm{COOCH}_{3}$ ), 1.39 (s, $\left.3 \times \mathrm{H}-12,3 \times \mathrm{H}-13\right) .-{ }^{1} \mathrm{H}$ NMR (DMSO$\left.d_{6}\right): \delta=10.99$ (s, OH-5), 10.21 (s, OH-7), 6.50 (d, $J=$ $10.1 \mathrm{~Hz}, \mathrm{H}-4), 5.86$ (s, H-8), 5.54 (d, $J=10.1 \mathrm{~Hz}, \mathrm{H}-3), 3.86$ $\left(\mathrm{s}, \mathrm{COOCH}_{3}\right), 1.35(\mathrm{~s}, 3 \times \mathrm{H}-12,3 \times \mathrm{H}-13) ;{ }^{13} \mathrm{C}\left\{{ }^{1} \mathrm{H}\right\} \mathrm{NMR}$ $\left(\mathrm{CDCl}_{3}\right): \delta=169.7$ (C-11), 160.5 (C-5, C-7, C-9), 125.8 (C-3), 115.9 (C-4), 102.2 (C-10), 96.6 (C-8), 93.4 (C-6), $77.6(\mathrm{C}-2), 52.4\left(\mathrm{COOCH}_{3}\right), 28.2(\mathrm{C}-12, \mathrm{C}-13) .-{ }^{13} \mathrm{C}\left\{{ }^{1} \mathrm{H}\right\}$ NMR (DMSO- $d_{6}$ ): $\delta=170.3(\mathrm{C}-11), 160.8(\mathrm{C}-7), 158.7$ (C9), 156.8 (C-5), 125.9 (C-3), 115.5 (C-4), 101.3 (C-10), $95.8(\mathrm{C}-8), 95.0(\mathrm{C}-6), 77.2(\mathrm{C}-2), 52.4\left(\mathrm{COOCH}_{3}\right), 27.7(\mathrm{C}-$ 12, C-13). - MS (EI, $70 \mathrm{eV}): m / z,(\%)=250(12)[\mathrm{M}]^{+}$, 235 (24), 217 (10), 203 (100), 175 (2), 147 (1), 135 (2), 117 (1), 101 (2), 91 (3), 69 (7), 55 (1). - HREIMS: $m / z=$ $250.0841[\mathrm{M}]^{+}$(calcd. for $\mathrm{C}_{13} \mathrm{H}_{14} \mathrm{O}_{5} 250.0841$ ).

Methyl 7-hydroxy-5-methoxy-2,2-dimethyl-2H-chromene-8carboxylate (5)

Yellow oil. - UV $\left(\mathrm{CHCl}_{3}\right): \lambda_{\max }=285,332(\mathrm{~nm}) .-\mathrm{IR}($ film $)$ $v=3435,2925,2855,1635,1445,1260,1125,1100$, $810 \mathrm{~cm}^{-1} .-{ }^{1} \mathrm{H}$ NMR $\left(\mathrm{CDCl}_{3}\right): \delta=11.82(\mathrm{~s}, \mathrm{OH}-7), 6.46$ (d, $J=9.8 \mathrm{~Hz}, \mathrm{H}-4), 6.00$ (s, H-6), 5.39 (d, $J=9.8 \mathrm{~Hz}, \mathrm{H}-3$ ), $3.84\left(\mathrm{~s}, \mathrm{COOCH}_{3}\right), 3.76\left(\mathrm{~s}, \mathrm{OCH}_{3}\right), 1.36(\mathrm{~s}, 3 \times \mathrm{H}-12,3 \times \mathrm{H}-$ 13). $-{ }^{13} \mathrm{C}\left\{{ }^{1} \mathrm{H}\right\}$ NMR $\left(\mathrm{CDCl}_{3}\right): \delta=171.6(\mathrm{C}-11), 164.6(\mathrm{C}-$ 7), 160.1 (C-5), 155.6 (C-9), 125.2 (C-3), 116.4 (C-4), 103.7 (C-10), 96.9 (C-8), 92.0 (C-6), 76.8 (C-2), 55.6 (OMe7), $51.8\left(\mathrm{COOCH}_{3}\right), 27.6(\mathrm{C}-12, \mathrm{C}-13)$. - MS (EI, $\left.70 \mathrm{eV}\right)$ : $\mathrm{m} / \mathrm{z}(\%)=264(10)[\mathrm{M}]^{+}, 249(19), 235$ (6), $217(100)$, 202 (4), 173 (11), 147 (1), 132 (1), 114 (1), 103 (2), 91 (2), 69 (4), 55 (1). - HREIMS: $m / z=264.0996[\mathrm{M}]^{+}$(calcd. for $\mathrm{C}_{14} \mathrm{H}_{16} \mathrm{O}_{5}$ 264.0998).

Acknowledgement

We are grateful to the DAAD for a research fellowship awarded to H.F.

[8] C. Steinbeck, V. Spitzer, M. Starosta, G. von Poser, J. Nat. Prod. 60, 627 (1997).

[9] F. Gomez, L. Quijano, A. Calderon, A. Perales, T. Rios, Phytochemistry 21, 2095 (1982).

[10] M. Ashan, J. A. Armstrong, S. Gibbons, A. I. Gray, P. G. Waterman, Phytochemistry 37, 259 (1994).

[11] Y. Asakawa, K. Kendo, M. Tori, T. Hashimoto, S. Ogawa, Phytochemistry 30, 219 (1991).

[12] Y. Asakawa, T. Hashimoto, K. Takikawa, M. Tori, S. Ogawa, Phytochemistry 30, 235 (1991).

[13] L. Kraut, R. Mues, H. D. Zinsmeister, Phytochemistry 45, 1249 (1997).

[14] B. Bläs, H. Becker, unpublished results (2000). 